Check for updates

Cite this: RSC Adv., 2019, 9, 24688

\title{
Evaluation of the antioxidant activities of fatty polyhydroquinolines synthesized by Hantzsch multicomponent reactions $\uparrow$
}

\author{
Rafael Centuriao Brinkerhoff, ${ }^{a}$ Eduarda Santa-Helena, ${ }^{\text {b }}$ Paulo C. do Amaral, ${ }^{a}$ \\ Diego da C. Cabrera, ${ }^{a}$ Renata F. Ongaratto, ${ }^{a}$ Patrick M. de Oliveira, ${ }^{a}$ Caroline Da Ros \\ Montes D'Oca, ${ }^{a}$ Carla A. Neves Gonçalves, ${ }^{b}$ Luiz E. Maia Nery ${ }^{\mathrm{b}}$ and Marcelo G. Montes \\ D'Oca (D) *a
}

\begin{abstract}
Polyhydroquinolines (PHQs) are the unsymmetrical Hantzsch derivatives of 1,4-dihydropyridines with several biological applications. In this work, new fatty 2- and 3-substituted PHQ derivatives from different fatty acids and fatty alcohol feedstocks were synthesized at good yields via a four-component reaction (4CR). The antioxidant activities of fatty PHQs were investigated using three different antioxidant methods. The experiments showed that the compounds derived from 2-nitrobenzaldehyde and fatty palmitic (C16:0) and oleic (C18:1) chains showed better antioxidant activity. This revealed that combining the ortho $\mathrm{NO}_{2}$ group in the aromatic ring with the insertion of fatty chains in the PHQ core contributed to the antioxidant activity. However, among all the fatty PHQs tested, the fatty 2-substituted compound derived from oleyl alcohol and 2-nitrobenzaldehyde showed the highest antioxidant activity $\left(\mathrm{EC}_{50}, 2.11-\right.$ $4.69 \mu \mathrm{M}$ ), which was similar to those of the antioxidant standards butylated hydroxytoluene $\left(\mathrm{EC}_{50}, 1.98-\right.$ $6.47 \mu \mathrm{M})$ and vitamin $E\left(E_{50}, 1.19-5.88 \mu \mathrm{M}\right)$. In addition, this lipophilic compound showed higher antioxidant activity than the antihypertensive drug nifedipine $\left(\mathrm{EC}_{50}, 49.25-126.86 \mu \mathrm{M}\right)$. These results indicate that the new fatty PHQs may find novel applications as antioxidant additives.
\end{abstract}

Received 24th June 2019 Accepted 25th July 2019 DOI: $10.1039 / c 9 r a 04758 a$ rsc.li/rsc-advances

\section{Introduction}

Dihydropiridines (DHPs) were synthesized for the first time by Arthur Hantzsch more than 130 years ago through a simple and efficient process: a multicomponent reaction (MCR) between an aldehyde, two equivalents of a $\beta$-ketoester, and a nitrogen donor such as ammonium acetate or ammonia. ${ }^{1}$ MCRs entail reactions among three components (3CR) or more components at the same time in a single step. ${ }^{2}$ However, harsh reaction conditions, excess reagents, high temperatures, toxic solvents, expensive catalysts, demanding purifications, and low yields are the major limitations of MCRs. In addition, MCRs have recently been recognized as a major expansion of the synthetic chemist's toolbox to obtain small biologically active molecules. Beside this, the multicomponent process, according to some criteria established by sustainable or green chemistry, is regarded as having environmentally friendly and

a Programa de Pós-graduação em Química Tecnológica e Ambiental, Laboratório Kolbe de Síntese Orgânica, Universidade Federal do Rio Grande, Av. Itália, Km 08 s/n, Rio Grande, RS, Brazil.E-mail: dqmdoca@furg.br

${ }^{b}$ Programa de Pós-graduação em Ciências Fisiológicas, Universidade Federal do Rio Grande, Av. Itália, $\mathrm{Km}$ os s/n, Rio Grande, RS, Brazil

$\dagger$ Electronic supplementary information (ESI) available: ${ }^{1} \mathrm{H}$ and ${ }^{13} \mathrm{C}$ NMR spectra of the compounds. See DOI: 10.1039/c9ra04758a efficient reaction conditions, resulting in better yields, selectivity, and atom economy. ${ }^{3}$

1,4-Dihydropyridines, also called 1,4-DHPs or Hantzsch compounds, are important precursors due to their pharmacological and biological (e.g., antihypertensive and anti-anginal) activities as well as the ability to aid calcium channel blockade, thereby reducing the risk of cardiovascular diseases. ${ }^{4}$ The 1,4-DHP scaffold serves as a nucleus for several commercial drugs such as nifedipine (1st generation), felodipine and nitrendipine (2nd generation), and amlodipine (3rd generation) (Fig. 1). ${ }^{5,6}$

Polyhydroquinolines (PHQs, Fig. 1) are the unsymmetrical Hantzsch derivatives of 1,4-DHPs obtained via a fourcomponent process (4CR), and many methodologies have been reported for their synthesis. ${ }^{7-9}$ In recent years, much consideration has been given to the synthesis of the PHQ

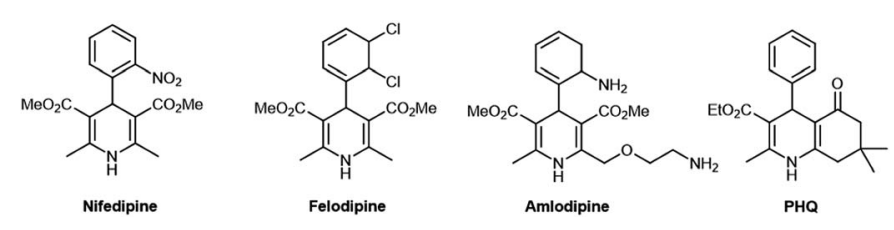

Fig. 1 Synthetic bioactive Hantzsch adducts. 
derivatives because of their pharmacological significance, which makes them potential targets for a number of biological applications. ${ }^{10-13}$ However, the important results around these small biologically active molecules have inspired further research to identify new, similar substances with diverse structures and to better understand the relationship between the variation in the chemical structure and biological activity.

Numerous studies indicate that oxidative stress plays an important role in the development and progress of illness, particularly age-related neurodegenerative diseases, and the antioxidants and free radical scavengers found in foods and dietary supplements have beneficial effects on the health of consumers. The antioxidant and antiradical properties have been ascribed primarily to polyphenols such as flavonoids and phenolic acids. $^{\mathbf{1 4}}$

Natural products are almost an inexhaustible source of antioxidant substances, which can play an important role in the treatment of human diseases. However, it remains a major challenge to design an effective and fast assay that would enable the identification of the most active plant extracts as well as individually isolated compounds. ${ }^{15}$

Antioxidant substances are important because of their wide applications in foodstuffs, medical remedies, and other products such as fuels. These substances are important because they increase the safety and quality of food that is consumed and protect from the action of oxidizing substances that can cause diseases. ${ }^{16-18}$

Several interrelated factors such as the decrease in the cellular ATP levels and the production of both reactive oxygen species (ROS) and reactive nitrogen species contribute to damage after myocardial ischemia and reperfusion (I/R), ${ }^{19}$ which is the leading cause of morbidity and mortality associated with cardiovascular diseases, a global public health problem. ${ }^{\mathbf{1 6 , 2 0 , 2 1}}$ Thus, antioxidants may be able to help overcome this situation.

For example, Santa-Helena et al. ${ }^{22}$ described the synthesis of new fatty Hantzsch compounds from the insertion of two palmitic chains in a nifedipine core, creating 3,5-dipalmitoyl nifedipine. It demonstrated an antioxidant effect, reducing the ROS formation and improving the cellular viability up to $138.7 \%$ in the H9c2 cardioblasts submitted for I/R simulation. In another study, the antioxidant activity of fatty DHPs was evaluated using a linoleic acid emulsion system as a substrate to mediate lipid peroxidation. This was a non-enzymatic method induced by two pro-oxidants iron $\left(\mathrm{Fe}^{2+}\right)$ /ascorbic acid (AA) and sodium nitroprusside (NPS). ${ }^{23}$ The fatty DHPs increased the cell viability during $\mathrm{I} / \mathrm{R}$ simulation and reduced the levels of ROS compared to the $\mathrm{I} / \mathrm{R}$ group, demonstrating the antioxidant capacity of the new DHPs. Furthermore, the experimental results showed that DHPs with palmitic and oleic acids in the $\mathrm{C} 3$ and $\mathrm{C} 5$ positions with $\mathrm{NO}_{2}$ or $\mathrm{Cl}$ in the aromatic moiety had the highest antioxidant potential (as assessed using the linoleic oxidant test).

Recently, Cabrera et $a .^{24}$ modified a DHP core by inserting fatty chains and demonstrated an important antioxidant behavior in this class of compounds using three different methods, namely, the 2,20-azino-bis-(3-ethylbenzthiazoline-6- sulfonic acid) (ABTS), ferric ion reducing antioxidant power (FRAP), and 1,1-diphenyl-2-picrylhydrazyl (DPPH) radical scavenging assays. Symmetrical and unsymmetrical long-chain fatty DHPs (di- and mono-substituted, respectively) were tested for antioxidant activity and the insertion of a fatty chain into the DHP core contributed to antioxidant potential. All symmetrical fatty DHPs showed higher antioxidant activity than nifedipine (no fatty analogue). However, those with hydroxyl or methoxyl groups in the aromatic rings and furfural derivatives showed less activity than other fatty DHPs. Among all of the investigated DHPs, the fatty analogs derived from 2-nitrobenzaldehyde and palmitic and oleic chains showed a better antioxidant potential than nifedipine and similar activity to those of the common antioxidant standards butylated hydroxytoluene (BHT) and vitamin E. In addition, the best radical scavenging activities were also observed for unsymmetrical mono fatty-substituted DHPs derived from furfural and 4-chlorobenzaldehyde.

Other researchers generated DHPs and PHQs via Hantzsch reactions and reported that the compounds derived from lignin, containing a methoxy moiety in the aromatic moiety, exhibited good activities compared to vitamin $\mathrm{C}$ and Trolox. ${ }^{25,26}$ This suggested that some synthesized compounds may serve as promising candidates for the development of treatments against tumors or other free radical-related diseases. In addition, all compounds in both studies showed good antioxidant capacity compared to AA.

Thus, different Hantzsch compounds have exhibited exciting results related to antioxidant activities, with better outcomes than the important classic antioxidants such as vitamins $\mathrm{E}$ and $\mathrm{C}$, Trolox, and BHT. Therefore, the synthesis of new substances with an antioxidant potential is a very important endeavor.

In addition, according to previous works, compounds with fatty chains incorporated into their central core may lead to the best biological activities, including antioxidant activity, compared to non-fatty analogues. ${ }^{22,24,27,28}$

In this work, we synthesized long-chain fatty 2- and 3substituted PHQs from different fatty chains using Hantzsch MCRs and verified, for the first time, the antioxidant activities of the resultant compounds using three different methods. Based on previous results, we synthesized fatty PHQs with nitro and chlorine groups attached to an aromatic ring. ${ }^{24}$

\section{Results and discussion}

Initially, fatty alcohols and fatty acids were used as precursors to synthesize fatty $\beta$-ketoesters (FBKEs) using previously reported methods. ${ }^{29,30}$ FBKEs 1a, 1b and 1c were synthesized by the transesterification of methyl acetoacetate from palmitic (C16:0), stearic (C18:0), and oleyl (C18:1) alcohols, respectively. At the same time, the FBKE precursors $2 \mathbf{a}, \mathbf{2 b}$ and $2 \mathbf{c}$ were synthesized via Meldrum's acid acylation with the corresponding fatty acids, followed by a decarboxylation step using methanol (Scheme 1).

Afterwards, the synthesis of fatty 2- and 3-substituted PHQs was performed using FBKEs 1a-c and 2a-c, aldehydes 3-8, 1,3cyclohexanedione (6), and ammonium acetate (7). MCR was performed in the presence of $30 \mathrm{~mol} \%$ sulfamic acid $\left(\mathrm{H}_{3} \mathrm{~N}^{+} \mathrm{SO}_{3}{ }^{-}\right.$, SA) as a catalyst and methanol as a solvent (Scheme 


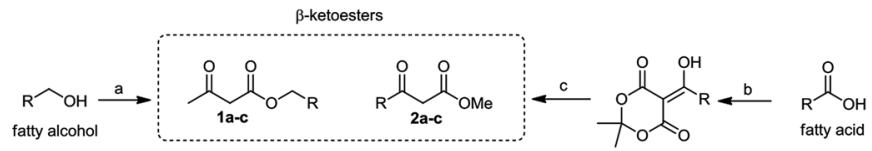

$$
R=\gamma_{14} \gamma_{16} \gamma_{T_{7}}=T_{7}
$$

a: methyl acetoacetate, sulfamic acid, $12 \mathrm{~h}$ at $80^{\circ} \mathrm{C}$

a: methyl acetoacetate, sulfamic acid, $12 \mathrm{~h}$ at $80^{\circ} \mathrm{C}$.
b: 1) DCC, DMAP, pyridine, methylene chloride 2) Meldrum 's acid, methylene chloride, $24 \mathrm{~h}$ at $25^{\circ} \mathrm{C}$.

c: methanol, $24 \mathrm{~h}$ at $65^{\circ} \mathrm{C}$.

Scheme 1 Synthesis of FBKE precursors $1 \mathrm{a}-\mathrm{c}$ and $2 \mathrm{a}-\mathrm{c}$

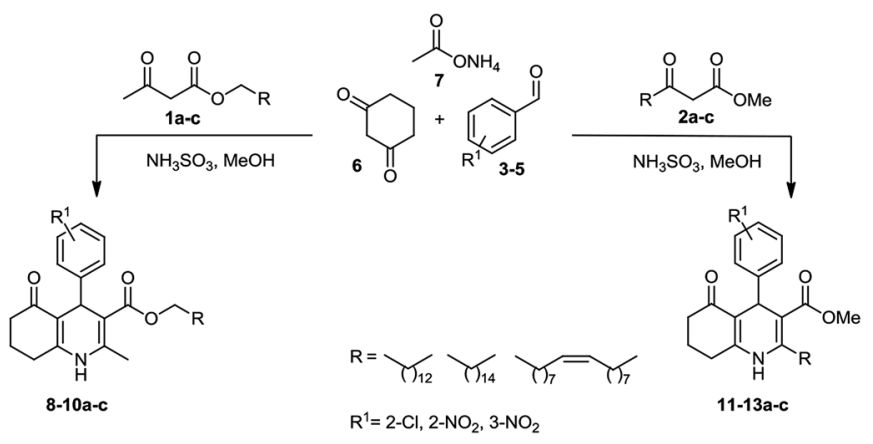

Scheme 2 Synthesis of fatty PHQs $8-13 a-c$.

2). ${ }^{31-33}$ Our approach provided good catalytic activity due to the synergetic effects between the polar and protic solvent and the SA zwitterionic salt. ${ }^{34}$ In addition, SA is a green catalyst that is relatively stable, odorless, non-volatile, non-hygroscopic, noncorrosive, and inexpensive. The results are described in Table 1.

\section{Antioxidant assays}

The antioxidant activities of PHQs were evaluated using three different methods, namely, $\mathrm{ABTS}^{+}$[2,20-azino-bis-(3 ethylbenzthiazoline-6-sulfonic acid)], DPPH (2,2-diphenyl-1picrylhydrazyl) radical scavenging and FRAP (ferric ion reducing antioxidant power) assays. BHT and vitamin E were used as the standards for antioxidant activity, and nifedipine (an antihypertensive drug) was used as a Hantzsch reference compound.

ABTS $^{+}$radical scavenging. Fatty PHQs 8-13a-c were tested for free radical scavenging using the $\mathrm{ABTS}^{+}$assay (Table 2). ${ }^{35}$ The results were reported as the minimal concentrations required to reduce the initial ABTS radical by $50 \%\left(\mathrm{EC}_{50}, \mu \mathrm{M}\right)$. All fatty PHQs showed higher antioxidant activity than nifedipine. Moreover, the activities of the fatty compounds were much higher than those of the non-fatty analogues, evidencing the importance of the presence of the fatty chain in the PHQ core. The best radical scavenging activities were observed for fatty PHQs 9a-c and 12a-c derived from 2-nitrobenzaldehyde. Compound $12 \mathrm{c}\left(\mathrm{EC}_{50}, 3.80 \mu \mathrm{M}\right)$ derived from oleic acid and 2nitrobenzaldehyde showed the highest activity, which was similar to those of BHT and vitamin E.

DPPH radical scavenging. The test results of free DPPH radical scavenging ${ }^{33}$ for fatty PHQs were reported as $\mathrm{EC}_{50}$ values $(\mu \mathrm{M})$ (Table 2). In general, the antioxidant activity results were similar to those obtained using the ABTS method, but the $\mathrm{EC}_{50}$ values were lower. The DPPH radical is by far the most used reagent for detecting and quantifying the antioxidant and radical scavenging activity. ${ }^{14}$ It is a stable free radical (hydrazyl) with a violet color and it converts into the yellow reduced form DPPH-H (hydrazine) in the presence of a compound that can donate a hydrogen atom. ${ }^{36}$ All the fatty PHQs presented satisfactory results compared to the non-fatty compound nifedipine. The best scavenging abilities were observed for fatty PHQs 9a$\mathbf{d}$ and 12a-c derived from 2-nitrobenzaldehyde.

The radical scavenging abilities of PHQs $12 \mathrm{a}\left(\mathrm{EC}_{50}, 2.42 \mu \mathrm{M}\right)$ and $12 \mathrm{c}\left(\mathrm{EC}_{50}, 2.11 \mu \mathrm{M}\right)$ derived from palmitic and oleic acids, respectively, and 2-nitrobenzaldehyde were the highest; the $\mathrm{EC}_{50}$ values were nearly similar to that of vitamin $\mathrm{E}\left(\mathrm{EC}_{50}, 2.36\right.$ $\mu \mathrm{M})$ and lower than BHT $\left(\mathrm{EC}_{50}, 3.14 \mu \mathrm{M}\right)$. Compounds $9 \mathrm{a}\left(\mathrm{EC}_{50}\right.$, $4.10 \mu \mathrm{M})$ and $9 \mathrm{c}\left(\mathrm{EC}_{50}, 3.68 \mu \mathrm{M}\right)$ derived from palmitic and oleic chains, respectively, and 3-nitrobenzaldehyde also demonstrated good antioxidant activity, which were similar to that of BHT.

Ferric ion reducing antioxidant power (FRAP) assay. Unlike DPPH and ABTS, the FRAP assay involves the reduction of iron ions, assuming that the antioxidant activity is correlated with the reducing power of the compound.$^{37}$ In this test, compounds 9a, 10a, 12a and 9c, 10c, 12c derived from palmitic and oleic chains, respectively, exhibited better results than BHT and vitamin E. Furthermore, the compounds derived from 2-nitrobenzaldehyde showed better activities than those derived from 3-nitrobenzaldehyde. Overall, all compounds showed better results than the non-fatty analogue nifedipine similar to that observed in other assays.

Interestingly, unlike the other tests, in the FRAP assay, of all the fatty PHQs tested, compound $9 \mathrm{a}\left(\mathrm{EC}_{50}, 4.19 \mu \mathrm{M}\right)$ derived from palmitic alcohol and 2-nitrobenzaldehyde showed similar antioxidant activity to that of compound $12 \mathrm{c}\left(\mathrm{EC}_{50}, 4.69 \mu \mathrm{M}\right)$ derived from oleic acid and 2-nitrobenzaldehyde. However, both showed better activity than the antioxidant standards BHT $\left(\mathrm{EC}_{50}, 6.47 \mu \mathrm{M}\right)$ and vitamin $\mathrm{E}\left(\mathrm{EC}_{50}, 5.88 \mu \mathrm{M}\right)$.

As shown in Table 2, in general, all the $\mathrm{EC}_{50}$ values for fatty PHQs are lower in the DPPH test and higher in the $\mathrm{ABTS}^{+}$test. In addition, $\mathrm{BHT}$ and vitamin $\mathrm{E}$ showed lower $\mathrm{EC}_{50}$ values in the $\mathrm{ABTS}^{+}$assay and better antioxidant activity than fatty PHQs.

After a closer look at the data, it was possible to observe a potential association between having a nitro group attached to an aromatic moiety and antioxidant activity, leading to better results than that for the other derivatives. In addition, the fatty PHQs derived from 2-chlorophenyl (8a-c and 10a-c) and 3nitrophenyl (11a-c and 13a-c) showed poor results, with the worst performance observed for the chlorinated derivatives 2fatty substituted PHQs 8a-c. These results were in agreement with previous results. ${ }^{23,24}$ However, in all cases, the insertion of the fatty chains in the PHQ core contributed to the antioxidant activity. This finding was supported by the fact that all fatty PHQs exhibited higher antioxidant activity than nifedipine.

In accordance with the results mentioned above, the fatty PHQs derived from the fatty palmitic (C16:0) and oleic (C18:1) chains showed, in all cases, better activity than those derived from the stearic (C18:0) fatty chains. In addition, regardless of 
Table 1 Yields of new lipophilic 2- and 3-substituted PHQs 8-13a-c

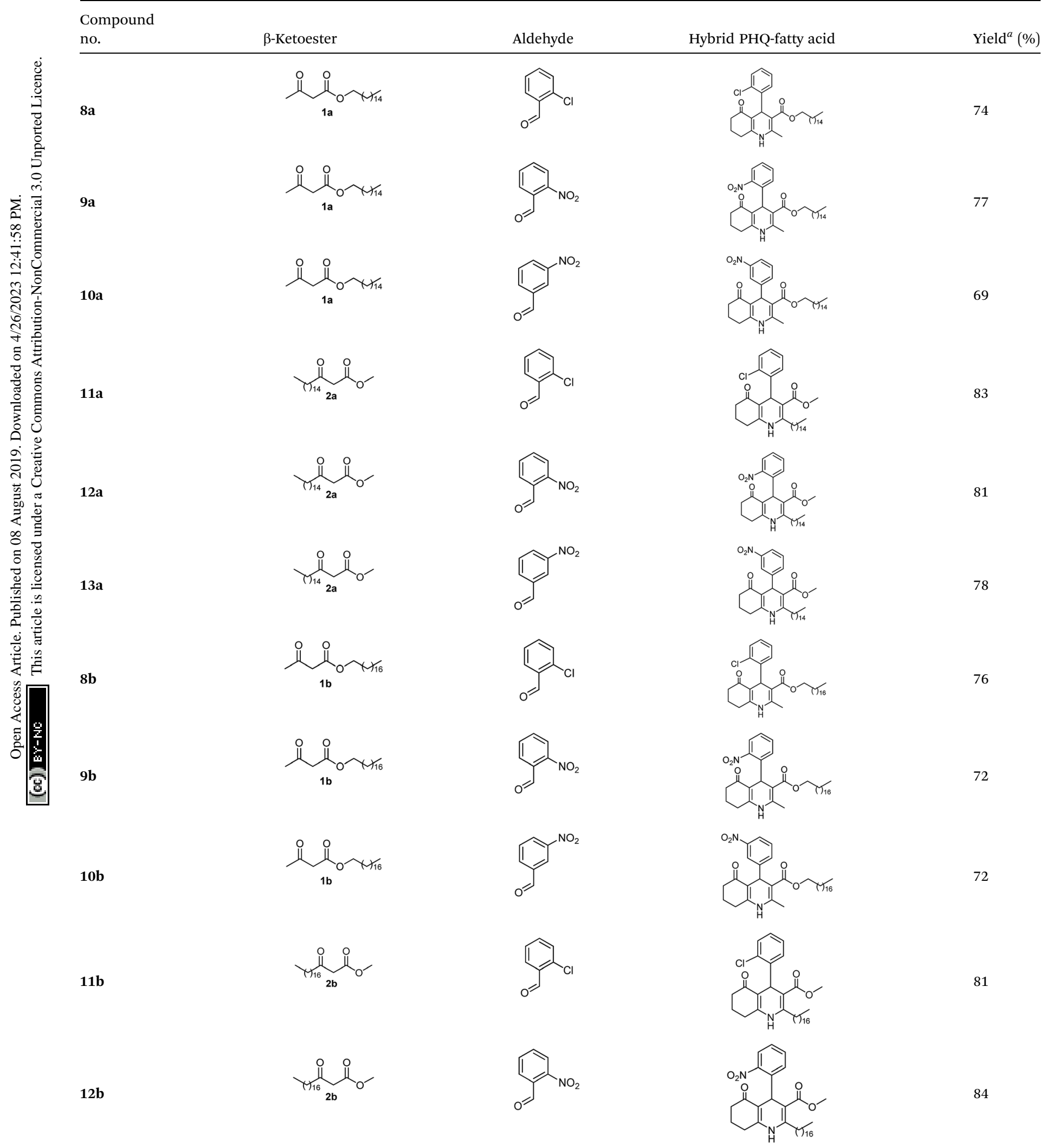


Table 1 (Contd.)

\section{Compound}

no.

$13 b$

$8 c$

$10 \mathrm{c}$

11c

12c

13c<smiles>CCC(=O)CC(=O)OC</smiles><smiles>CC=CC=CCOC(=O)CC(C)=O</smiles>

$1 c$<smiles>CCCCCCOC(=O)CC(C)=O</smiles>

$1 c$<smiles>CC=CC=CCOC(=O)CC(C)=O</smiles><smiles>C/C=C\C=C\C(=O)CC(=O)OC</smiles>

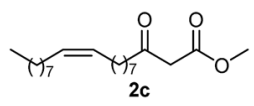<smiles>O=Cc1cccc([N+](=O)[O-])c1</smiles><smiles>O=Cc1ccccc1Cl</smiles><smiles>O=Cc1ccccc1[N+](=O)[O-]</smiles><smiles>O=Cc1cccc([N+](=O)[O-])c1</smiles><smiles>O=Cc1ccccc1Cl</smiles><smiles>CC=CC=CCC(=O)CC(=O)OC</smiles><smiles>O=Cc1ccccc1[N+](=O)[O-]</smiles><smiles>O=Cc1cccc([N+](=O)[O-])c1</smiles>

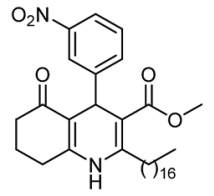<smiles>CC=CC=CCOC(=O)C1=C(C)NC2=C(C(=O)CCC2)C1c1ccccc1Cl</smiles><smiles>CC(=[Pt])/C=C\COC(=O)C1=C(C)NC2=C(C(=O)CCC2)C1c1ccccc1[N+](=O)[O-]</smiles><smiles>CCCCCCOC(=O)C1=C(C)NC2=C(C(=O)CCC2)C1c1cccc([N+](=O)[O-])c1</smiles><smiles>CCC=CC1=C(C(=O)OC)C(c2ccccc2Cl)C2=C(CCCC2=O)N1</smiles><smiles>CC=CC=CC1=C(C(=O)OC)C(c2ccccc2[N+](=O)[O-])C2=C(CCCC2=O)N1</smiles><smiles>CCC/C=C/C1=C(C(=O)OC)C(c2cccc([N+](=O)[O-])c2)C2=C(CCCC2=O)N1</smiles>

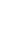

${ }^{a}$ Product purified by column chromatography.

the position and nature of the substituent group in the aromatic ring, all fatty PHQs derived from the oleic (C18:1) chains exhibited better activity than the PHQs derived from the palmitic (C16:0) and stearic (C18:0) chains. Thus, the insertion of an oleic chain in the PHQ core contributed to the antioxidant activity.

Another interesting observation was that the combination of the ortho $\mathrm{NO}_{2}$ group in the aromatic ring with the insertion of the C16:0 and C18:1 fatty chains in the PHQ core contributed to the antioxidant activity, resulting in lower $\mathrm{EC}_{50}$ values in the DPPH and FRAP assays (in the range of 2.11-5.06 $\mu \mathrm{M}$ ). In this case, the fatty PHQ derivatives obtained using 2-nitrobenzaldehyde and stearic (C18:0) alcohol or acid (fatty 2- or 3- substituted, respectively) showed poor activity with higher $\mathrm{EC}_{50}$ values (in the range of $4.27-10.33 \mu \mathrm{M}$ ).

These results were in agreement with those observed for fatty DHPs reported in a previous work ${ }^{24}$, demonstrating that the presence of the fatty $\mathrm{C} 16: 0$ and $\mathrm{C} 18: 1$ chains in the nifedipine core endowed the compound with an antioxidant effect. In this previous work, the fatty 2,6-disubstituted DHPs derived from 2nitrobenzaldehyde and substituted with palmitic and oleic chains presented $93.8 \%$ of variance in principal component analysis (PCA), showing similar antioxidant activities to the references vitamin $\mathrm{E}$ and $\mathrm{BHT}$ and better antioxidant activity than nifedipine.

Thus, cluster analysis was conducted to assess the activities of all the compounds investigated in this work and to compare 
Table 2 Antioxidant activity and calculated $\log P$ of new lipophilic fatty PHQs 8-13a-c<smiles>CCOC(=O)C1=C(C)NC2=C(C(=O)CCC2)C1Br</smiles>

PHQs 8-10a-c<smiles>[R]C1=C(C(=O)OC)C(Br)C2=C(CCCC2=O)N1</smiles>

PHQs 11-13a-c

\begin{tabular}{|c|c|c|c|c|c|c|}
\hline \multirow[b]{2}{*}{ Compound } & \multirow[b]{2}{*}{$\mathrm{R}^{1}$} & \multirow[b]{2}{*}{$\mathrm{Ar}$} & \multirow[b]{2}{*}{ Calc $\log P$} & \multicolumn{3}{|l|}{$\underline{\mathrm{EC}_{50}(\mu \mathrm{M})}$} \\
\hline & & & & ABTS & DPPH & FRAP \\
\hline $8 b$ & C18:0 & 2-Chlorophenyl & 8.24 & $34.25(32.82-35.77)$ & $17.88(16.30-20.13)$ & $25.48(23.33-27.75)$ \\
\hline $8 c$ & C18:1 & 2-Chlorophenyl & 7.92 & $21.48(19.91-23.15)$ & $7.42(6.24-9.56)$ & $19.64(20.63-20.95)$ \\
\hline $9 a$ & C16:0 & 2-Nitrophenyl & 8.71 & $5.34(4.73-6.07)$ & $4.10(3.22-5.57)$ & $4.19(3.62-5.89)$ \\
\hline $10 a$ & C16:0 & 3-Nitrophenyl & 8.71 & $10.85(9.20-11.51)$ & $7.12(5.74-8.66)$ & $5.64(4.02-8.39)$ \\
\hline $10 b$ & C18:0 & 3-Nitrophenyl & 9.62 & $19.01(17.43-20.57)$ & $9.35(8.13-10.68)$ & $13.42(11.91-15.24)$ \\
\hline $10 \mathrm{c}$ & C18:1 & 3-Nitrophenyl & 8.91 & $11.26(10.09-12.45)$ & $6.74(5.40-7.83)$ & $6.03(5.47-7.14)$ \\
\hline $11 \mathrm{a}$ & C16:0 & 2-Chlorophenyl & 7.06 & $23.73(21.56-25.39)$ & $8.62(7.11-10.60)$ & $17.99(15.74-19.48)$ \\
\hline $11 b$ & C18:0 & 2-Chlorophenyl & 7.90 & $29.63(28.83-31.47)$ & $13.55(12.82-14.37)$ & $21.13(20.45-22.59)$ \\
\hline $11 \mathrm{c}$ & C18:1 & 2-Chlorophenyl & 7.58 & $15.29(14.78-16.62)$ & $5.96(4.53-7.48)$ & $16.51(14.27-18.02)$ \\
\hline $13 b$ & C18:0 & 3-Nitrophenyl & 9.34 & $15.39(14.22-16.81)$ & $7.47(5.90-8.87)$ & $11.36(9.75-12.40)$ \\
\hline $13 \mathrm{c}$ & C18:1 & 3-Nitrophenyl & 8.62 & $8.92(7.13-10.64)$ & $4.72(3.85-5.93)$ & $6.86(5.61-8.15)$ \\
\hline & & & 11.90 & $1.19(0.92-1.48)$ & $2.36(1.89-2.56)$ & $5.88(4.84-7.42)$ \\
\hline & & & 5.32 & $1.98(1.53-2.26)$ & $3.14(2.77-3.51)$ & $6.47(6.09-7.28)$ \\
\hline & & & 2.97 & $126.86(84.0-146.41)$ & $52.60(34.5-51.90)$ & $49.25(36.34-47.66)$ \\
\hline
\end{tabular}

their antioxidant activities. The results are shown in Fig. 2. In the DPPH radical scavenging and FRAP assays, compounds 9a, 9c, and 12a with the nitro group in the 2-position of the aromatic moiety presented similar results to those for BHT and vitamin E. However, in these assays, compound 12c, a fatty 2-substituted PHQ derived from oleic acid and 2nitrobenzaldehyde, showed the highest antioxidant activity $\left(\mathrm{EC}_{50}, 2.11\right.$ and $4.69 \mu \mathrm{M}$ from DPPH and FRAP, respectively) than the standards BHT and vitamin E. In addition, for the ABTS $^{+}$, DPPH and FRAP assays, compounds 9a, 9c, 12a and 12c showed better antioxidant activities than the antihypertensive drug nifedipine.
In addition, in agreement with the behavior observed for fatty DHPs in previous works that employed ${ }^{1} \mathrm{H}$ NMR spectral data, ${ }^{24}$ we observed that the benzylic hydrogen for fatty PHQs exhibited a chemical shift that was more deshielded than that for other PHQ derivatives (Fig. 3). In this case, the fatty PHQs showed chemical displacement for the benzylic hydrogen, which ranged from 5.64 to $5.81 \mathrm{ppm}$ for the compounds derived from 2-nitrobenzaldehyde, while the other aromatic moietysubstituted compounds showed lower chemical displacement for the benzylic hydrogen (5.00 to $5.42 \mathrm{ppm}$ ). In addition, the fatty 2-substituted PHQs exhibited a chemical shift for the benzylic hydrogen that was more deshielded (5.81 ppm) than 


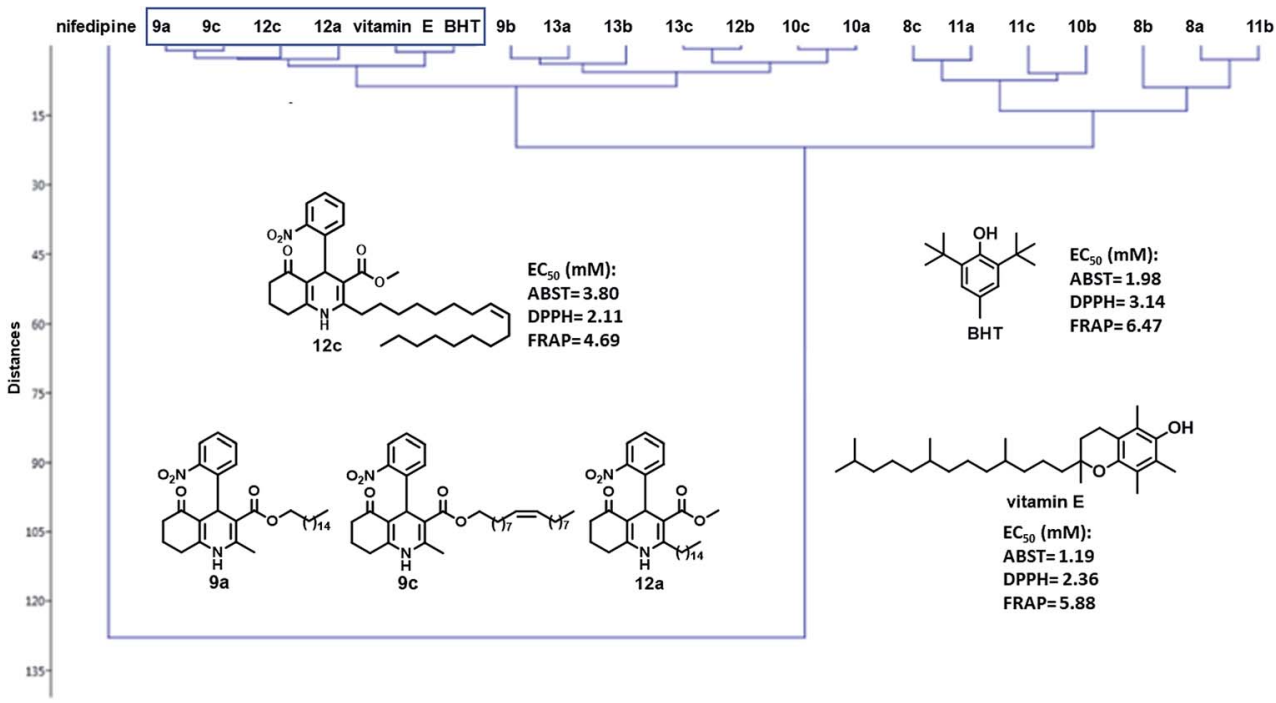

Fig. 2 The dendrogram showing the clustering for the antioxidant activity of fatty PHQs.

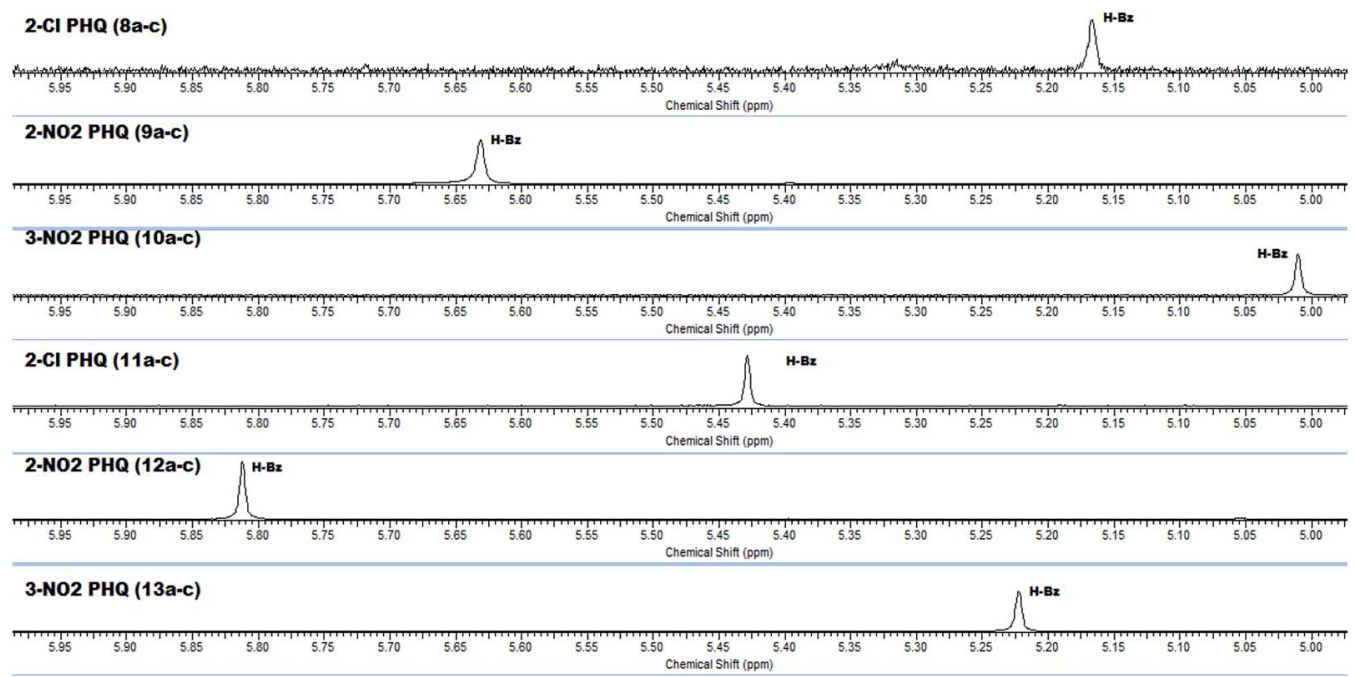

Fig. $3{ }^{1} \mathrm{H}$ NMR spectra (400 MHz, $\mathrm{CDCl}_{3}, 5.00-5.95$ ppm region) of fatty $\mathrm{PHQs}(\mathrm{H}-\mathrm{Bz}=$ benzylic hydrogen).

that for the fatty 3-substituted PHQs (5.64 ppm). This finding may explain the highest antioxidant activity of the fatty 2nitrobenzaldehyde PHQ derivative 12c, which was correlated with the aromatization of the pyridine ring and the antioxidant activity of this compound.

\section{Conclusion}

In this work, new fatty PHQs were synthesized with good yields using a Hantzsch MCR protocol. Their antioxidant activities were investigated using three different methods, and the results were compared to those of classic antioxidants BHT, vitamin E, and the antihypertensive drug nifedipine. In general, the compounds presented better results than nifedipine, indicating that the fatty chain attached to the PHQ core contributed to the antioxidant effect. In addition, the compounds with a nitro group attached to the 2-position of the aromatic moiety showed similar results to those of BHT and vitamin E. Moreover, compound 12c derived from oleic acid and 2-nitrobenzaldehyde exhibited lower $\mathrm{EC}_{50}$ values and similar antioxidant activity to those of the antioxidant standards BHT and vitamin E; it also showed better antioxidant activity compared to the antihypertensive drug nifedipine. Finally, in the ${ }^{1} \mathrm{H}$ NMR spectral analyses, fatty 2-substituted PHQs derived from 2nitrobenzaldehyde exhibited a chemical shift that was more deshielded than those of other PHQs, corroborating the aromatization of the pyridine ring and supporting the antioxidant activity of this compound.

These results were in agreement with those observed in previous works for fatty DHPs, confirming that the nitro group in the ortho position of the aromatic moiety and the fatty oleic chain attached to the central structure of the Hantzsch compounds conferred a high antioxidant effect. Thus, these substances have a great potential in antioxidant-related 
applications involving food, medical areas, and other products such as fuels and oils.

\section{Experimental section}

\section{Apparatus and chemistry}

Sulfamic acid, methyl acetoacetate, ammonium acetate and aromatic aldehydes were purchased from Sigma-Aldrich Chemical Co. and used without purification. All organic solvents used for the synthesis were of analytical grade. Column chromatography was performed using silica gel $60 \AA$ (ACROS Organics, $0.035-0.070 \mathrm{mesh}$ ). The reactions were monitored by thin-layer chromatography (TLC) performed on glass plates coated with silica gel (Merck 60GF245); a mixture of hexane : ethyl acetate was used as the eluent, and the products were visualized using iodine vapor. The melting points were obtained using a Fisatom 430D apparatus and were reported as uncorrected values. ${ }^{1} \mathrm{H}$ NMR and ${ }^{13} \mathrm{C}$ NMR spectra were recorded on Bruker Ascend $400 \mathrm{MHz}$ operating at $400 \mathrm{MHz}$ and $100 \mathrm{MHz}$, respectively, in deuterated chloroform $\left(\mathrm{CDCl}_{3}\right)$ as the solvent. The chemical shift data were reported in units of $\delta$ (ppm) downfield from tetramethylsilane (TMS), which was used as an internal standard. Infrared spectra were obtained using potassium bromide $(\mathrm{KBr})$ pellets or sodium chloride $(\mathrm{NaCl})$ disks on a Shimadzu-IR Prestige-21 spectrometer.

\section{Synthesis}

General procedure for the synthesis of fatty acid PHQs 813a-c

Synthesis of fatty polyhydroquinolines $\mathbf{8 - 1 0 a - c}$. In a round bottom flask equipped with a reflux condenser, we added two equivalents of fatty $\beta$-ketoester 1a-c $(1 \mathrm{mmol})$, aromatic aldehyde $(3-5,1 \mathrm{mmol})$, ammonium acetate $(7,3 \mathrm{mmol}), 1,3-$ cyclohexanedione $(6,1 \mathrm{mmol})$ and sulphamic acid $(30 \mathrm{~mol} \%)$ as a catalyst in the presence of methanol $(5 \mathrm{~mL})$. The reaction mixture was stirred constantly at reflux and monitored by TLC. After $24 \mathrm{~h}$, the crude mixture was cooled to an ambient temperature, concentrated under vacuum and purified by a chromatography column with a gradient elution of hexane : ethyl acetate to afford the fatty PHQ in a good yield.

Synthesis of fatty polyhydroquinolines 11-13a-c. In a round bottom flask equipped with a reflux condenser, we added two equivalents of fatty $\beta$-ketoester $\mathbf{2 a - c}(1 \mathrm{mmol})$, aromatic aldehyde (3-5, $1 \mathrm{mmol})$, ammonium acetate $(7,3 \mathrm{mmol}), 1,3-$ cyclohexanedione $(6,1 \mathrm{mmol})$ and sulphamic acid $(30 \mathrm{~mol} \%)$ as a catalyst in the presence of methanol $(5 \mathrm{~mL})$. The reaction mixture was stirred constantly at reflux and monitored by TLC. After $48 \mathrm{~h}$, the crude mixture was cooled to an ambient temperature, concentrated under vacuum and purified by a chromatography column with a gradient elution of hexane : ethyl acetate to afford the fatty PHQ in a good yield.

Hexadecyl 4-(2-chlorophenyl)-2-methyl-5-oxo-1,4,5,6,7,8-hexahydro -quinoline-3-carboxilate (8a). Yield 74\%; M.W. $541 \mathrm{~g} \mathrm{~mol}^{-1}$. White solid; mp 130-132 ${ }^{\circ} \mathrm{C} ;{ }^{1} \mathrm{H}$ NMR (400 MHz, DMSO- $\left.d_{6}\right): \delta 0.87(\mathrm{t}, J=$ $\left.7.0 \mathrm{~Hz}, 3 \mathrm{H}, \mathrm{CH}_{3}\right), 1.25\left(\mathrm{~m}, 26 \mathrm{H}, \mathrm{CH}_{2}\right), 1.46(\mathrm{~m}, 2 \mathrm{H}), 1.72(\mathrm{~m}, 1 \mathrm{H})$, $1.88(\mathrm{~m}, 1 \mathrm{H}), 2.14-2.23(\mathrm{~m}, 5 \mathrm{H}), 3.91(\mathrm{~m}, 2 \mathrm{H}), 5.20(\mathrm{~s}, 1 \mathrm{H}), 7.04(\mathrm{t}, J$
$=7.5 \mathrm{~Hz}, 1 \mathrm{H}, \mathrm{CH}), 7.17(\mathrm{~m}, 2 \mathrm{H}), 7.27$ (d. $J=7.7 \mathrm{~Hz}, 1 \mathrm{H}), 8.98(\mathrm{~s}$, $1 \mathrm{H}, \mathrm{NH}) ;{ }^{13} \mathrm{C}$ NMR (100 MHz, DMSO- $\left.d_{6}\right): \delta 14.4,18.6,21.2,22.6$, 25.8, 26.7, 28.7, 29.1, 29.3, 29.7, 31.8, 35.2, 37.2, 63.5, 103.7, 111.3, 127.2, 127.4, 129.4, 131.9, 132.4, 145.4, 145.8, 152.0, 167.3, 194.6; $\operatorname{IR}\left(\mathrm{KBr}, \nu_{\max } \mathrm{cm}^{-1}\right): 1070,1119,1184,1223,1290,1379,1485,1601$, 1699, 2849, 2916, 3070, 3198, 3290.

Hexadecyl 2-methyl-4-(2-nitrophenyl)-5-oxo-1,4,5,6,7,8-hexahydroquinoline-3-carboxilate (9a). Yield 77\%; M.W. $552 \mathrm{~g} \mathrm{~mol}^{-1}$. Yellow solid; mp $111-113{ }^{\circ} \mathrm{C} ;{ }^{1} \mathrm{H}$ NMR $\left(400 \mathrm{MHz}\right.$, DMSO- $\left.d_{6}\right): \delta 0.85(\mathrm{~m}$, $\left.3 \mathrm{H}, \mathrm{CH}_{3}\right), 1.10-1.24\left(\mathrm{~m}, 24 \mathrm{H}, \mathrm{CH}_{2}\right), 1.36(\mathrm{~m}, 2 \mathrm{H}), 1.66(\mathrm{~m}, 1 \mathrm{H}), 1.83$ $(\mathrm{m}, 1 \mathrm{H}), 2.10(\mathrm{~m}, 2 \mathrm{H}), 2.30\left(\mathrm{~s}, 3 \mathrm{H}, \mathrm{CH}_{3}\right), 2.42(\mathrm{~m}, 2 \mathrm{H}), 3.86(\mathrm{~s}, 2 \mathrm{H})$, $5.64(\mathrm{~s}, 1 \mathrm{H}, \mathrm{CH}), 7.28(\mathrm{t}, J=7.2 \mathrm{~Hz}, 1 \mathrm{H}, \mathrm{CH}), 7.40(\mathrm{~d}, J=7.9 \mathrm{~Hz}, 1 \mathrm{H}$, $\mathrm{CH}), 7.54(\mathrm{t}, J=7.2 \mathrm{~Hz}, 1 \mathrm{H}, \mathrm{CH}), 7.66(\mathrm{~d}, J=7.9 \mathrm{~Hz}, 1 \mathrm{H}, \mathrm{CH}), 9.19$ $(\mathrm{s}, 1 \mathrm{H}, \mathrm{NH}) ;{ }^{13} \mathrm{C}$ NMR $\left(100 \mathrm{MHz}\right.$, DMSO- $\left.d_{6}\right): \delta 14.4,18.7,21.1,22.4$, 25.7, 26.6, 27.9, 28.4, 29.1, 29.3, 29.4, 31.7, 32.4, 36.9, 63.6, 103.3, 111.5, 123.9, 127.2, 131.2, 133.2, 142.4, 146.4, 148.3, 152.0, 167.1, 194.8; IR (KBr, $\left.\nu_{\max } \mathrm{cm}^{-1}\right): 1076,1111,1182,1232,1350,1494$, 1525, 1627, 1693, 1724, 2848, 2918, 3086, 3205, 3304.

Hexadecyl 2-methyl-4-(3-nitrophenyl)-5-oxo-1,4,5,6,7,8-hexahydroquinoline-3-carboxilate (10a). Yield 69\%; M.W. $552 \mathrm{~g} \mathrm{~mol}^{-1}$. Yellow solid; mp 119-120. ${ }^{\circ} \mathrm{C} ;{ }^{1} \mathrm{H}$ NMR ( $400 \mathrm{MHz}$, DMSO- $\left.d_{6}\right): \delta 0.85$ $\left(\mathrm{t}, J=6.3 \mathrm{~Hz}, 3 \mathrm{H}, \mathrm{CH}_{3}\right), 1.24\left(\mathrm{~m}, 26 \mathrm{H}, \mathrm{CH}_{2}\right), 1.44(\mathrm{~m}, 2 \mathrm{H}), 1.72-1.89$ (m, 2H), $2.19(\mathrm{~m}, 2 \mathrm{H}), 2.34(\mathrm{~m}, 2 \mathrm{H}), 3.87-3.93(\mathrm{~m}, 2 \mathrm{H}), 5.01(\mathrm{~s}, 1 \mathrm{H}$, $\mathrm{CH}), 7.52(\mathrm{t}, J=7.8 \mathrm{~Hz}, 1 \mathrm{H}, \mathrm{CH}), 7.59(\mathrm{~d}, J=7.8 \mathrm{~Hz}, 1 \mathrm{H}, \mathrm{CH}), 7.98$ (m, 2H, 2CH), 9.34 (s, 1H, NH); IR (KBr, $\left.\nu_{\max } \mathrm{cm}^{-1}\right): 1080,1182$, 1222, 1344, 1379, 1479, 1525, 1606, 1705, 2850, 2918, 2951, 3078, 3221, 3296.

Methyl 4-(2-chlorophenyl)-5-oxo-2-pentadecyl-1,4,5,6,7,8-hexahydroquinoline-3-carboxilate (11a). Yield 83\%; M.W. $527 \mathrm{~g} \mathrm{~mol}^{-1}$. White solid; mp 121-122 ${ }^{\circ} \mathrm{C} ;{ }^{1} \mathrm{H}$ NMR $\left(400 \mathrm{MHz}, \mathrm{CDCl}_{3}\right): \delta 0.90(\mathrm{~m}, 3 \mathrm{H}$, $\left.\mathrm{CH}_{3}\right), 1.27-1.32\left(\mathrm{~m}, 23 \mathrm{H}, \mathrm{CH}_{2}\right), 1.60(\mathrm{~m}, 2 \mathrm{H}), 1.95(\mathrm{~m}, 2 \mathrm{H}), 2.31(\mathrm{~m}$, $2 \mathrm{H}), 2.42(\mathrm{~m}, 2 \mathrm{H}), 2.55(\mathrm{~m}, 1 \mathrm{H}), 2.82(\mathrm{~m}, 1 \mathrm{H}), 3.60\left(\mathrm{~s}, 3 \mathrm{H}, \mathrm{CH}_{3}\right), 5.43$ (s, 1H, CH), $6.34(\mathrm{~s}, 1 \mathrm{H}, \mathrm{NH}), 7.05(\mathrm{~m}, 1 \mathrm{H}, \mathrm{CH}), 7.13(\mathrm{td}, J=7.5$ and $1.2 \mathrm{~Hz}, 1 \mathrm{H}, \mathrm{CH}), 7.25(\mathrm{dd}, J=7.8$ and $1.2 \mathrm{~Hz}, 1 \mathrm{H}, \mathrm{CH}), 7.37(\mathrm{dd}, J=$ 7.8 and $1.6 \mathrm{~Hz}, 1 \mathrm{H}, \mathrm{CH}) ;{ }^{13} \mathrm{C}$ NMR $\left(100 \mathrm{MHz}, \mathrm{CDCl}_{3}\right): \delta 14.1,21.0$, 22.7, 27.5, 28.6, 29.4, 29.5, 29.6, 29.7, 31.9, 32.5, 35.9, 37.0, 40.7, 50.8, 104.8, 126.4, 127.2, 129.6, 131.7, 144.4, 147.9, 150.3, 167.5, 195.4; IR $\left(\mathrm{KBr}, \nu_{\max } \mathrm{cm}^{-1}\right): 1085,1114,1180,1220,1301,1390,1494,1604$, 1645, 1703, 2850, 2922, 3061, 3282, 3273.

Methyl 4-(2-nitrophenyl)-5-oxo-2-pentadecyl-1,4,5,6,7,8-hexahydroquinoline-3-carboxilate (12a). Yield 81\%; M.W. $538 \mathrm{~g} \mathrm{~mol}^{-1}$. Yellow solid; mp $112-113{ }^{\circ} \mathrm{C} ;{ }^{1} \mathrm{H}$ NMR $\left(400 \mathrm{MHz}, \mathrm{CDCl}_{3}\right): \delta 0.90(\mathrm{~m}$, $\left.3 \mathrm{H}, \mathrm{CH}_{3}\right), 1.27-1.38\left(\mathrm{~m}, 23 \mathrm{H}, \mathrm{CH}_{2}\right), 1.64(\mathrm{~m}, 5 \mathrm{H}), 1.91-2.00(\mathrm{~m}, 2 \mathrm{H})$, $2.31(\mathrm{~m}, 2 \mathrm{H}), 2.45(\mathrm{~m}, 2 \mathrm{H}), 2.66(\mathrm{~m}, 1 \mathrm{H}), 2.81(\mathrm{~m}, 1 \mathrm{H}), 3.59(\mathrm{~s}, 3 \mathrm{H}$, $\left.\mathrm{OCH}_{3}\right), 5.80(\mathrm{~s}, 1 \mathrm{H}, \mathrm{CH}), 5.95(\mathrm{~s}, 1 \mathrm{H}, \mathrm{NH}), 7.29(\mathrm{~m}, 1 \mathrm{H}, \mathrm{CH}), 7.45$ $(\mathrm{m}, 2 \mathrm{H}, 2 \mathrm{CH}), 7.70(\mathrm{~m}, 1 \mathrm{H}, \mathrm{CH}) ;{ }^{13} \mathrm{C} \mathrm{NMR}\left(100 \mathrm{MHz}, \mathrm{CDCl}_{3}\right): \delta 14.1$, 20.9, 21.3, 22.7, 27.6, 28.5, 29.4, 29.5, 29.6, 31.9, 32.6, 33.2, 36.7, 37.1, 39.6, 51.0, 104.8, 110.0, 112.7, 124.1, 126.8, 128.1, 129.4, 131.1, 135.1, 141.2, 148.4, 167.2, 195.1; IR (KBr, $\left.\nu_{\max } \mathrm{cm}^{-1}\right): 1074$, 1114, 1180, 1222, 1305, 1350, 1490, 1527, 1597, 1701, 1734, 2850, 2922, 3066, 3180, 3267.

Methyl 4-(3-nitrophenyl)-5-oxo-2-pentadecyl-1,4,5,6,7,8-hexahydroquinoline-3-carboxilate (13a). Yield 78\%; M.W. $538 \mathrm{~g} \mathrm{~mol}^{-1}$. Yellow solid; mp $108-111{ }^{\circ} \mathrm{C} ;{ }^{1} \mathrm{H}$ NMR $\left(400 \mathrm{MHz}, \mathrm{CDCl}_{3}\right): \delta 0.89$ (t, $J$ $\left.=7.3 \mathrm{~Hz}, 3 \mathrm{H}, \mathrm{CH}_{3}\right), 1.27\left(\mathrm{~m}, 24 \mathrm{H}, \mathrm{CH}_{2}\right), 1.64(\mathrm{~m}, 2 \mathrm{H}), 1.93-2.03(\mathrm{~m}$, $2 \mathrm{H}), 2.38-2.50(\mathrm{~m}, 4 \mathrm{H}), 2.71-2.87(\mathrm{~m}, 2 \mathrm{H}), 3.63\left(\mathrm{~s}, 3 \mathrm{H}, \mathrm{OCH}_{3}\right), 5.22$ $(\mathrm{s}, 1 \mathrm{H}, \mathrm{CH}), 6.63(\mathrm{~s}, 1 \mathrm{H}, \mathrm{NH}), 7,40(\mathrm{t}, J=7.6 \mathrm{~Hz}, 1 \mathrm{H}, 1 \mathrm{CH}), 7.74(\mathrm{~d}, J$ 
$=8.2 \mathrm{~Hz}, 1 \mathrm{H}, \mathrm{CH}), 7.99(\mathrm{t}, J=7.6 \mathrm{~Hz}, 1 \mathrm{H}, \mathrm{CH}), 8.09(\mathrm{~s}, 1 \mathrm{H}, \mathrm{CH}) ;{ }^{13} \mathrm{C}$ NMR (100 MHz, $\left.\mathrm{CDCl}_{3}\right): \delta$ 14.1, 21.0, 22.7, 27.4, 28.7, 29.4, 29.5, 29.6, 29.7, 29.8, 31.9, 32.6, 36.6, 36.7, 51.0, 104.2, 112.3, 121.3, 122.6, 128.7, 134.0, 148.4, 149.2, 149.3, 149.4, 150.7, 167.0, 195.7; IR ( $\left.\mathrm{KBr}, \nu_{\max } \mathrm{cm}^{-1}\right): 1064,1180,1224,1348,1471,1529,1605,1705$, 2850, 2918, 3072, 3215, 3309.

Octadecyl 4-(2-chlorophenyl)-2-methyl-5-oxo-1,4,5,6,7,8-hexahydroquinoline-3-carboxilate (8b). Yield 76\%; M.W. $569 \mathrm{~g} \mathrm{~mol}^{-1}$. White solid; mp 132-134 ${ }^{\circ} \mathrm{C} ;{ }^{1} \mathrm{H}$ NMR (400 MHz, DMSO- $\left.d_{6}\right): \delta 0.80(\mathrm{t}, J=$ $\left.7.5 \mathrm{~Hz}, 3 \mathrm{H}, \mathrm{CH}_{3}\right), 1.20\left(\mathrm{~m}, 28 \mathrm{H}, \mathrm{CH}_{2}\right), 1.41(\mathrm{t}, J=8.0 \mathrm{~Hz}, 2 \mathrm{H}), 1.67$ (m, 1H), $1.80(\mathrm{~m}, 1 \mathrm{H}), 2.04-2.11(\mathrm{~m}, 5 \mathrm{H}), 3.84(\mathrm{t}, J=8.0 \mathrm{~Hz}, 2 \mathrm{H})$, $5.15(\mathrm{~s}, 1 \mathrm{H}), 6.99(\mathrm{t}, J=8.0 \mathrm{~Hz}, 1 \mathrm{H}), 7.11(\mathrm{~m}, 2 \mathrm{H}), 7.22(\mathrm{~d}, J=8.0 \mathrm{~Hz}$, $1 \mathrm{H}), 8.94(\mathrm{~s}, 1 \mathrm{H}, \mathrm{NH}) ;{ }^{13} \mathrm{C}$ NMR (100 MHz, DMSO- $\left.d_{6}\right): \delta 14.3,18.6$, 21.2, 22.5, 25.8, 26.8, 28.7, 29.1, 29.3 (2C), 29.4, 31.7, 35.6, 37.3, $63.5,103.9,111.3,127.1,127.5,129.4,132.0,132.5,145.1,145.8$, 151.9, 167.5, 194.6; IR (KBr, $\left.\nu_{\max } \mathrm{cm}^{-1}\right)$ : 1070, 1118, 1184, 1222, 1286, 1377, 1485, 1598, 1651, 1703, 2848, 2912, 2953, 3072, 3180, 3267.

Octadecyl 2-methyl-4-(2-nitrophenyl)-5-oxo-1,4,5,6,7,8-hexahydroquinoline-3-carboxilate (9b). Yield 72\%; M.W. $580 \mathrm{~g} \mathrm{~mol}^{-1}$. Yellow solid; mp $120-122{ }^{\circ} \mathrm{C} ;{ }^{1} \mathrm{H}$ NMR (400 MHz, DMSO- $\left.d_{6}\right): \delta 0.84(\mathrm{~m}$, $3 \mathrm{H}), 1.23-1.38(\mathrm{~m}, 28 \mathrm{H}), 1.67(\mathrm{~m}, 2 \mathrm{H}), 1.82(\mathrm{~m}, 1 \mathrm{H}), 1.85(\mathrm{~m}, 1 \mathrm{H})$, 2.07 (m, 2H), 2.30 (s, 3H), $2.43(\mathrm{~m}, 2 \mathrm{H}), 3.84(\mathrm{~s}, 3 \mathrm{H}), 5.63(\mathrm{~s}, 1 \mathrm{H})$, $7.29(\mathrm{t}, J=7.6 \mathrm{~Hz}, 1 \mathrm{H}), 7.41(\mathrm{~d}, J=8.0 \mathrm{~Hz}, 1 \mathrm{H}), 7.54(\mathrm{t}, J=7.5 \mathrm{~Hz}$, $1 \mathrm{H}), 7.66(\mathrm{~d}, J=8.0 \mathrm{~Hz}, 1 \mathrm{H}), 9.21(\mathrm{~s}, 1 \mathrm{H}, \mathrm{NH}) ;{ }^{13} \mathrm{C}$ NMR $(100 \mathrm{MHz}$, DMSO- $d_{6}$ ): $\delta 14.4,18.8,21.1,22.6,25.7,26.7,28.5,29.1,29.2,29.3$, 29.4, 29.5, 31.8, 32.4, 37.0, 63.6, 103.3, 111.5, 124.0, 127.2, 131.2, 133.3, 142.5, 146.4, 148.3, 152.0, 167.1, 194.7; IR (KBr, $\left.\nu_{\max } \mathrm{cm}^{-1}\right)$ : 1072, 1111, 1182, 1232, 1354, 1489, 1525, 1627, 1662, 1693, 2848, 2916, 3086, 3207, 3302.

Octadecyl 2-methyl-4-(3-nitrophenyl)-5-oxo-1,4,5,6,7,8-hexahydroquinoline-3-carboxilate (10b). Yield 72\%; M.W. $580 \mathrm{~g} \mathrm{~mol}{ }^{-1}$. White solid; mp 120-122 ${ }^{\circ} \mathrm{C} ;{ }^{1} \mathrm{H}$ NMR $\left(400 \mathrm{MHz}, \mathrm{CDCl}_{3}\right): \delta 0.90(\mathrm{~m}$, $\left.3 \mathrm{H}, \mathrm{CH}_{3}\right), 1.28\left(\mathrm{~m}, 30 \mathrm{H}, \mathrm{CH}_{2}\right), 1.54(\mathrm{~m}, 2 \mathrm{H}), 1.65$ (sl, 1H, NH), 1.94$2.05(\mathrm{~m}, 2 \mathrm{H}), 2.37(\mathrm{~m}, 2 \mathrm{H}), 2.45\left(\mathrm{~s}, 3 \mathrm{H}, \mathrm{CH}_{3}\right), 2.48(\mathrm{~m}, 2 \mathrm{H}), 4.00(\mathrm{~m}$, $2 \mathrm{H}), 5.21(\mathrm{~s}, 1 \mathrm{H}, \mathrm{CH}), 7.40(\mathrm{t}, J=7.9 \mathrm{~Hz}, 1 \mathrm{H}, \mathrm{CH}), 7.76(\mathrm{~d}, J=$ $7.6 \mathrm{~Hz}, 1 \mathrm{H}, \mathrm{CH}), 7.98(\mathrm{~m}, 1 \mathrm{H}, \mathrm{CH}), 8.01(\mathrm{~m}, 1 \mathrm{H}, \mathrm{CH}) ;{ }^{13} \mathrm{C} \mathrm{NMR}(100$ $\left.\mathrm{MHz}, \mathrm{CDCl}_{3}\right): \delta 14.1,19.4,21.0,22.7,26.0,27.4,28.6,29.2,29.3$, 29.5, 29.6, 29.7, 31.9, 36.9, 64.3, 105.0, 115.5, 121.2, 122.8, 128.6, 134.9, 144.5, 148.4 149.3, 150.3, 167.0, 195.7; IR (KBr, $\left.\nu_{\max } \mathrm{cm}^{-1}\right)$ : 1083, 1136, 1184, 1224, 1344, 1386, 1491, 1524, 1601, 1647, 1705, 2850, 2918, 2947, 3076, 3201, 3275.

Methyl 2-heptadecyl-4-(2-chlorophenyl)-5-oxo-1,4,5,6,7,8-hexahydroquinoline-3-carboxilate (11b). Yield 81\%; M.W. $555 \mathrm{~g} \mathrm{~mol}^{-1}$. White solid; mp 110-111 ${ }^{\circ} \mathrm{C} ;{ }^{1} \mathrm{H}$ NMR (400 MHz, $\left.\mathrm{CDCl}_{3}\right): \delta 0.90(\mathrm{~m}, 3 \mathrm{H}$, $\left.\mathrm{CH}_{3}\right), 1.27$ (m, 26H, $\left.\mathrm{CH}_{2}\right), 1.60-1.66(\mathrm{~m}, 4 \mathrm{H}), 1.93-1.98(\mathrm{~m}, 2 \mathrm{H}), 2.31$ $(\mathrm{m}, 2 \mathrm{H}), 2.43(\mathrm{~m}, 2 \mathrm{H}), 2.56(\mathrm{~m}, 1 \mathrm{H}), 2.84(\mathrm{~m}, 1 \mathrm{H}), 3.60\left(\mathrm{~s}, 3 \mathrm{H}, \mathrm{OCH}_{3}\right)$, $5.43(\mathrm{~s}, 1 \mathrm{H}, \mathrm{CH}), 6.05(\mathrm{~s}, 1 \mathrm{H}, \mathrm{NH}), 7.05(\mathrm{td}, J=7.5$ and $1.5 \mathrm{~Hz}, 1 \mathrm{H}$, $\mathrm{CH}), 7.13(\mathrm{t}, J=7.5 \mathrm{~Hz}, 1 \mathrm{H}, \mathrm{CH}), 7.25(\mathrm{~m}, 1 \mathrm{H}, \mathrm{CH}), 7.36(\mathrm{dd}, J=7.7$ and $1.4 \mathrm{~Hz}, 1 \mathrm{H}, \mathrm{CH}) ;{ }^{13} \mathrm{C} \mathrm{NMR}\left(100 \mathrm{MHz}, \mathrm{CDCl}_{3}\right): \delta 14.1,21.0,22.7$, 27.5, 29.4, 29.5, 29.6, 29.7, 32.5, 35.9, 36.9, 50.8, 104.8, 112.4, 126.4, 127.2, 129.7, 131.8, 133.3, 144.4, 147.8, 150.0, 167.5, 195.3; IR (KBr, $\nu_{\text {max }} \mathrm{cm}^{-1}$ ): 1072, 1114, 1178, 1220, 1300, 1377, 1489, 1627, 1699, 2850, 2918, 3064, 3170, 3273.

Methyl 2-heptadecyl-4-(2-nitrophenyl)-5-oxo-1,4,5,6,7,8-hexahydro-

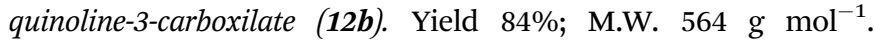
Yellow solid; mp $109-110{ }^{\circ} \mathrm{C} ;{ }^{1} \mathrm{H}$ NMR (400 MHz, $\left.\mathrm{CDCl}_{3}\right): \delta 0.89(\mathrm{~m}$, $\left.3 \mathrm{H}, \mathrm{CH}_{3}\right), 1.27$ (m, 26H, $\left.\mathrm{CH}_{2}\right), 1.60(\mathrm{~m}, 2 \mathrm{H}), 1.80-1.98(\mathrm{~m}, 3 \mathrm{H}), 2.30$ (m, 2H), $2.45(\mathrm{~m}, 2 \mathrm{H}), 2.64(\mathrm{~m}, 1 \mathrm{H}), 2.78(\mathrm{~m}, 1 \mathrm{H}), 3.58(\mathrm{~s}, 3 \mathrm{H}$, $\left.\mathrm{OCH}_{3}\right), 5.81(\mathrm{~s}, 1 \mathrm{H}, \mathrm{CH}), 6.46(\mathrm{~s}, 1 \mathrm{H}, \mathrm{NH}), 7.23(\mathrm{t}, J=8.4 \mathrm{~Hz}, 1 \mathrm{H}$, $\mathrm{CH}), 7.46(\mathrm{~m}, 2 \mathrm{H}, 2 \mathrm{CH}), 7.69$ (d, $J=7.8 \mathrm{~Hz}, 1 \mathrm{H}, \mathrm{CH}) ;{ }^{13} \mathrm{C}$ NMR $(100$ $\left.\mathrm{MHz}, \mathrm{CDCl}_{3}\right): \delta 14.1,21.0,22.3,27.4,28.6,29.5,32.5,32.9,33.5$, $36.8,37.1,39.5,51.0,104.6,112.5,124.0,126.8,13.1$; IR $(\mathrm{KBr}$, $\left.\nu_{\max } \mathrm{cm}^{-1}\right): 1074,1116,1180,1222,1352,1489,1527,1598,1701$, 2850, 2920, 3066, 3178, 3267.

Methyl 2-heptadecyl-4-(3-nitrophenyl)-5-oxo-1,4,5,6,7,8-hexahydroquinoline-3-carboxilate (13b). Yield 84\%; M.W. $566 \mathrm{~g} \mathrm{~mol} \mathrm{~mol}^{-1}$. Yellow solid; mp 110-112 ${ }^{\circ} \mathrm{C} ;{ }^{1} \mathrm{H}$ NMR $\left(400 \mathrm{MHz}, \mathrm{CDCl}_{3}\right): \delta 0.87(\mathrm{t}, J$ $\left.=6.5 \mathrm{~Hz}, 3 \mathrm{H}, \mathrm{CH}_{3}\right), 1.25\left(\mathrm{~m}, 24 \mathrm{H}, \mathrm{CH}_{2}\right), 1.62(\mathrm{~m}, 2 \mathrm{H}), 1.90-2.00(\mathrm{~m}$, $2 \mathrm{H}), 2.36(\mathrm{~m}, 2 \mathrm{H}), 2.50(\mathrm{~m}, 2 \mathrm{H}), 2.68-2.84(\mathrm{~m}, 2 \mathrm{H}), 3.61(\mathrm{~s}, 3 \mathrm{H}$, $\left.\mathrm{OCH}_{3}\right), 5.22(\mathrm{~s}, 1 \mathrm{H}, \mathrm{CH}), 7.39(\mathrm{t}, J=7.9 \mathrm{~Hz}, 1 \mathrm{H}, \mathrm{CH}), 7.72(\mathrm{~d}, J=$ $7.7 \mathrm{~Hz}, 1 \mathrm{H}, \mathrm{CH}), 7.98(\mathrm{~d}, J=8.0 \mathrm{~Hz}, 1 \mathrm{H}, \mathrm{CH}), 8.12(\mathrm{~s}, 1 \mathrm{H}, \mathrm{CH}) ;{ }^{13} \mathrm{C}$ NMR (100 MHz, $\left.\mathrm{CDCl}_{3}\right): \delta 14.1,21.0,22.7,27.1,28.9,29.4,29.5$, 29.6, 29.7, 31.9, 32.4, 36.6, 37.0, 51.2, 103.9, 111.9, 121.2, 128.8, 134.6, 148.3, 149.5, 149.9, 151.6, 167.1, 196.1; IR (KBr, $\left.\nu_{\max } \mathrm{cm}^{-1}\right)$ : 1180, 1225, 1348, 1472, 1529, 1605, 1705, 2851, 2918, 3072, 3215, 3310.

(Z)-Octadec-9-enyl 4-(2-chlorophenyl)-2-methyl-5-oxo-1,4,5,6,7,8hexahydroquinoline-3-carboxilate (8c). Yield 81\%; M.W. $567 \mathrm{~g}$ $\mathrm{mol}^{-1}$. White solid; mp 98-100 ${ }^{\circ} \mathrm{C} ;{ }^{1} \mathrm{H}$ NMR (400 MHz, DMSO- $d_{6}$ ): $\delta 0.83\left(\mathrm{~m}, 3 \mathrm{H}, \mathrm{CH}_{3}\right), 1.07-1.27\left(\mathrm{~m}, 22 \mathrm{H}, \mathrm{CH}_{2}\right), 1.46(\mathrm{~m}, 2 \mathrm{H}), 1.70-$ $1.97(\mathrm{~m}, 6 \mathrm{H}), 2.07-2.16(\mathrm{~m}, 2 \mathrm{H}), 2.25\left(\mathrm{~s}, 3 \mathrm{H}, \mathrm{CH}_{3}\right), 2.45(\mathrm{~m}, 2 \mathrm{H})$, $3.88(\mathrm{~m}, 2 \mathrm{H}), 5.20(\mathrm{~s}, 1 \mathrm{H}), 5.31(\mathrm{~m}, 2 \mathrm{H}), 7.03(\mathrm{~m}, 1 \mathrm{H}, \mathrm{CH}), 7.15(\mathrm{~m}$, $2 \mathrm{H}, 2 \mathrm{CH}), 7.27$ (m, 1H, CH), 9.14 (s, $1 \mathrm{H}, \mathrm{NH}) ;{ }^{13} \mathrm{C} \mathrm{NMR}(100 \mathrm{MHz}$, DMSO- $\left.d_{6}\right): \delta 14.3,18.6,21.2,22.6,25.9,26.7,27.1,28.7,29.0,29.1$, 29.2, 29.3, 29.4, 29.5, 29.6, 31.8, 32.4, 35.3, 37.2, 63.4, 103.7, 111.3, 127.1, 127.5, 129.3, 130.0, 130.4, 131.9, 132.5, 145.5, 145.9, 151.9, 167.2, 194.5; IR (KBr, $\nu_{\max } \mathrm{cm}^{-1}$ ): 1074, 1138, 1184, 1222, 1315, 1377, 1469, 1602, 1691, 2850, 2920, 3061, 3197, 3284.

(Z)-Octadec-9-enyl 2-methyl-4-(2-nitrophenyl)-5-oxo-1,4,5, 6, 7,8hexahydroquinoline-3-carboxilate (9c). Yield 79\%; M.W. $578 \mathrm{~g}$ $\mathrm{mol}^{-1}$. Yellow oil; ${ }^{1} \mathrm{H}$ NMR (400 MHz, DMSO- $\left.d_{6}\right): \delta 0.82(\mathrm{~m}, 3 \mathrm{H}$, $\left.\mathrm{CH}_{3}\right), 0.94(\mathrm{~m}, 2 \mathrm{H}), 1.10-1.36\left(\mathrm{~m}, 21 \mathrm{H}, \mathrm{CH}_{2}\right), 1.65(\mathrm{~m}, 1 \mathrm{H}), 1.82$ $(\mathrm{m}, 1 \mathrm{H}), 1.97(\mathrm{~m}, 4 \mathrm{H}), 2.13(\mathrm{~m}, 2 \mathrm{H}), 2.30\left(\mathrm{~s}, 3 \mathrm{H}, \mathrm{CH}_{3}\right), 2.43(\mathrm{t}, J=$ $5.7 \mathrm{~Hz}, 2 \mathrm{H}), 3.84(\mathrm{~m}, 2 \mathrm{H}), 5.30(\mathrm{~m}, 2 \mathrm{H}), 5.64(\mathrm{~s}, 1 \mathrm{H}), 7.26(\mathrm{t}, J=$ $7.4 \mathrm{~Hz}, 1 \mathrm{H}, \mathrm{CH}), 7.41(\mathrm{~d}, J=7.1 \mathrm{~Hz}, 1 \mathrm{H}, \mathrm{CH}), 7.53(\mathrm{t}, J=7.4 \mathrm{~Hz}$, $1 \mathrm{H}, \mathrm{CH}), 7.65$ (d, $J=8.3 \mathrm{~Hz}, 1 \mathrm{H}, \mathrm{CH}), 9.20(\mathrm{~s}, 1 \mathrm{H}, \mathrm{NH}) ;{ }^{13} \mathrm{C} \mathrm{NMR}$ (100 MHz, DMSO- $d_{6}$ ): $\delta 14.3,18.7,21.1,22.6,25.7,26.7,27.1$, 28.5, 28.8, 29.0, 29.1, 29.2, 29.3, 29.5, 29.6, 31.8, 32.4, 32.5, 37.0, $63.5,103.3,111.5,123.9,127.1,130.0,130.5,131.2,133.1,142.5$, 146.3, 148.4, 151.9, 167.1, 194.6; IR ( NaCl film, $\left.\nu_{\max } \mathrm{cm}^{-1}\right)$ : 1076, 1186, 1238, 1354, 1492, 1529, 1627, 1662, 1697, 2850, 2922, 3086, 3203.

(Z)-Octadec-9-enyl 2-methyl-4-(3-nitrophenyl)-5-oxo-1,4,5, 6, 7,8hexahydroquinoline-3-carboxilate (10c). Yield 74\%; M.W. $578 \mathrm{~g}$ $\mathrm{mol}^{-1}$. White solid; mp 97-98 ${ }^{\circ} \mathrm{C} ;{ }^{1} \mathrm{H}$ NMR (400 $\mathrm{MHz}, \mathrm{CDCl}_{3}$ ): $\delta 0.89\left(\mathrm{~m}, 3 \mathrm{H}, \mathrm{CH}_{3}\right), 1.28\left(\mathrm{~m}, 22 \mathrm{H}, \mathrm{CH}_{2}\right), 1.54(\mathrm{~m}, 2 \mathrm{H}), 2.02(\mathrm{~m}$, $6 \mathrm{H}), 2.01(\mathrm{~m}, 2 \mathrm{H}), 2.44\left(\mathrm{~m}, 3 \mathrm{H}, \mathrm{CH}_{3}\right), 2.49(\mathrm{~m}, 2 \mathrm{H}), 4.01(\mathrm{~m}, 2 \mathrm{H})$, $5.20(\mathrm{~s}, 1 \mathrm{H}, \mathrm{CH}), 5.36(\mathrm{~m}, 2 \mathrm{H}), 6.32-6.41(\mathrm{~m}, 1 \mathrm{H}, \mathrm{NH}), 7.39(\mathrm{t}, J=$ $7.8 \mathrm{~Hz}, 1 \mathrm{H}, \mathrm{CH}), 7.76(\mathrm{~d}, J=7.8 \mathrm{~Hz}, 1 \mathrm{H}, \mathrm{CH}), 8.00(\mathrm{~d}, J=8.1 \mathrm{~Hz}$, $1 \mathrm{H}, \mathrm{CH}), 8.10(\mathrm{~s}, 1 \mathrm{H}, \mathrm{CH}) ;{ }^{13} \mathrm{C} \mathrm{NMR}\left(100 \mathrm{MHz}, \mathrm{CDCl}_{3}\right): \delta 14.1$, 19.5, 21.0, 22.7, 24.4, 26.0, 27.2, 27.4, 28.6, 29.1, 29.2, 29.3, 29.4, 29.5, 29.6, 29.7, 29.8, 31.9, 32.6, 36.9, 45.0, 64.3, 105.0, 112.6, $121.3,122.8,128.6,129.8,129.9$, 130.3, 130.4, 134.9, 144.4, 
148.4, 149.3, 150.2, 167.0, 195.7; IR (KBr, $\left.\nu_{\max } \mathrm{cm}^{-1}\right): 1084,1184$, 1223, 1290, 1344, 1379, 1491, 1524, 1601, 1649, 1703, 2852, 2920, 3078, 3209, 3279.

Methyl (Z)-2-heptadec-8-enyl-4-(2-chlorophenyl)-5-oxo-1,4,5,6,7,8hexahydroquinoline-3-carboxilate (11c). Yield 84\%, M.W. $553 \mathrm{~g}$ $\mathrm{mol}^{-1}$. White solid, mp 99-101 ${ }^{\circ} \mathrm{C},{ }^{1} \mathrm{H}$ NMR (400 MHz, $\left.\mathrm{CDCl}_{3}\right): 0.90$ $\left(\mathrm{m}, 3 \mathrm{H}, \mathrm{CH}_{3}\right), 1.28\left(\mathrm{~m}, 20 \mathrm{H}, \mathrm{CH}_{2}\right), 1.60(\mathrm{~m}, 2 \mathrm{H}), 1.90-2.03(\mathrm{~m}, 6 \mathrm{H})$, $2.30(\mathrm{~m}, 2 \mathrm{H}), 2.41(\mathrm{~m}, 2 \mathrm{H}), 2.55(\mathrm{~m}, 1 \mathrm{H}), 2.77(\mathrm{~m}, 1 \mathrm{H}), 3.60(\mathrm{~s}, 3 \mathrm{H}$, $\left.\mathrm{OCH}_{3}\right), 5.36(\mathrm{~m}, 2 \mathrm{H}), 5.44(\mathrm{~s}, 1 \mathrm{H}, \mathrm{CH}), 6.77-6.95(\mathrm{~m}, 1 \mathrm{H}, \mathrm{NH}), 7.04(\mathrm{t}$, $J=7.1 \mathrm{~Hz}, 1 \mathrm{H}, \mathrm{CH}), 7.14$ (m, 1H, CH), 7.26 (m, 1H, CH), 7.38 (d, $J=$ $7.6 \mathrm{~Hz}, 1 \mathrm{H}, \mathrm{CH}),{ }^{13} \mathrm{C} \mathrm{NMR}\left(100 \mathrm{MHz}, \mathrm{CDCl}_{3}\right): \delta 14.1,21.0,22.7,28.6$, 29.6, 31.9, 32.0, 32.3, 35.8, 37.1, 51.0, 104.7, 112.2, 112.3, 126.5, 127.2, 129.6, 129.7, 129.8, 130.0, 131.7, 133.2, 144.7, 148.2, 151.0, 167.6, 195.6, IR (KBr, $\left.\nu_{\max } \mathrm{cm}^{-1}\right): 1083,1114,1178,1220,1301,1373$, 1489, 1647, 1703, 2850, 2926, 3062, 3174, 3271.

Methyl (Z)-2-heptadec-8-enyl-4-(2-nitrophenyl)-5-oxo-1,4,5,6,7,8hexahydroquinoline-3-carboxilate (12c). Yield 88\%, M.W. $562 \mathrm{~g}$ $\mathrm{mol}^{-1}$. Yellow oil, ${ }^{1} \mathrm{H}$ NMR (400 MHz, $\left.\mathrm{CDCl}_{3}\right): \delta 0.89\left(\mathrm{~m}, 3 \mathrm{H}, \mathrm{CH}_{3}\right)$, $1.28\left(\mathrm{~m}, 20 \mathrm{H}, \mathrm{CH}_{2}\right), 1.60(\mathrm{~m}, 2 \mathrm{H}), 1.78-1.90(\mathrm{~m}, 2 \mathrm{H}), 2.03(\mathrm{~m}, 3 \mathrm{H})$, $2.31(\mathrm{~m}, 2 \mathrm{H}), 2.46(\mathrm{~m}, 2 \mathrm{H}), 2.64(\mathrm{~m}, 1 \mathrm{H}), 2.77(\mathrm{~m}, 1 \mathrm{H}), 3.59(\mathrm{~s}, 3 \mathrm{H}$, $\left.\mathrm{OCH}_{3}\right), 5.38(\mathrm{~m}, 2 \mathrm{H}), 5.83(\mathrm{~m}, 1 \mathrm{H}), 6.54-6.68(\mathrm{~m}, 1 \mathrm{H}, \mathrm{NH}), 7.24(\mathrm{~m}$, $1 \mathrm{H}, \mathrm{CH}), 7.47(\mathrm{~m}, 2 \mathrm{H}, 2 \mathrm{CH}), 7.69(\mathrm{~d}, J=8.0 \mathrm{~Hz}, 1 \mathrm{H}, \mathrm{CH}),{ }^{13} \mathrm{C} \mathrm{NMR}$ (100 MHz, $\left.\mathrm{CDCl}_{3}\right): \delta 14.1,21.0,22.7,27.2,27.4,28.6,29.2,29.3$, 29.5, 29.6, 29.7, 31.9, 32.4, 32.9, 36.9, 51.0, 104.6, 112.5, 124.0, 126.8, 129.7, 129.8, 130.0, 131.1, 132.3, 141.5, 148.7, 148.9, 167.2, 195.4, IR (NaCl film, $\nu_{\max } \mathrm{cm}^{-1}$ ): 1074, 1132, 1180, 1222, 1305, 1352, 1489, 1527, 1597, 1647, 1701, 2852, 2924, 3066, 3184, 3271.

Methyl (Z)-2-heptadec-8-enyl-4-(3-nitrophenyl)-5-oxo-1,4,5,6,7,8-hexahydroquinoline-3-carboxilate (13c). Yield 87\%, M.W. $564 \mathrm{~g} \mathrm{~mol}^{-1}$. White solid, mp $96-97{ }^{\circ} \mathrm{C},{ }^{1} \mathrm{H}$ NMR $\left(400 \mathrm{MHz}, \mathrm{CDCl}_{3}\right): \delta 0.88(\mathrm{~m}, 3 \mathrm{H}$, $\left.\mathrm{CH}_{3}\right), 1.27-1.30\left(\mathrm{~m}, 24 \mathrm{H}, \mathrm{CH}_{2}\right), 1.64(\mathrm{~m}, 2 \mathrm{H}), 2.01(\mathrm{~m}, 7 \mathrm{H}), 2.36-2.49$ (m, 4H), 2.71-2.86 (m, 2H), $3.62\left(\mathrm{~s}, 3 \mathrm{H}, \mathrm{OCH}_{3}\right), 5.22(\mathrm{~s}, 1 \mathrm{H}, \mathrm{CH}), 5.35$ $(\mathrm{m}, 2 \mathrm{H}), 6.76(\mathrm{~s}, 1 \mathrm{H}, \mathrm{NH}), 7.38(\mathrm{t}, J=7.9 \mathrm{~Hz}, 1 \mathrm{H}, \mathrm{CH}), 7.73(\mathrm{~d}, J=$ $7.8 \mathrm{~Hz}, 1 \mathrm{H}, \mathrm{CH}), 7.99$ (d, J=8.1 Hz, 1H, CH), $8.10(\mathrm{~s}, 1 \mathrm{H}, \mathrm{CH}),{ }^{13} \mathrm{C}$ $\mathrm{NMR}\left(100 \mathrm{MHz}, \mathrm{CDCl}_{3}\right): \delta 14.1,21.9,22.7,27.2,28.8,29.2,29.3,29.5$, 29.6, 29.8, 31.9, 32.6, 36.9, 51.2, 104.1, 112.2, 121.3, 122.6, 128.7, 129.7, 130.0, 134.6, 148.4, 149.2, 149.5, 150.9, 167.0, 195.9, IR (KBr, $\left.\nu_{\max } \mathrm{cm}^{-1}\right): 1070,1184,1225,1344,1489,1524,1643,1707,2853$, 2924, 3078, 3202, 3279.

\section{ABTS radical scavenging}

The determination of the radical scavenging effects of hybrid fatty dihydropyridine on ABTS-2,2'-azino-bis-(3ethylbenzthiazoline-6-sulfonic acid) radicals was performed according to the method reported by Re et al. ${ }^{38}$ with some modifications. Briefly, the ABTS radical was added to a medium containing the DHP sample $(0.1 \mu \mathrm{M}, 1 \mu \mathrm{M}, 10 \mu \mathrm{M}$ and $100 \mu \mathrm{M})$. The media were incubated for $30 \mathrm{~min}$ at $25{ }^{\circ} \mathrm{C}$. The decrease in absorbance was measured at $734 \mathrm{~nm}$, which depicted the scavenging activity of compounds against the ABTS radical. The radical scavenging activity was expressed in $\mathrm{EC}_{50}$ (half maximal effective concentration). ${ }^{39}$

\section{DPPH photometric assay}

The effects of fatty polyhydroquinoline on DPPH (2,2-diphenyl1-picrylhydrazyl) radicals were measured using the method reported by Sharma and Bhat with some modifications. ${ }^{40}$ The compounds were diluted to final concentrations of $0.1 \mu \mathrm{M}, 1$ $\mu \mathrm{M}, 10 \mu \mathrm{M}$ and $100 \mu \mathrm{M}$. The reaction mixture was shaken thoroughly and incubated for $30 \mathrm{~min}$ at $30{ }^{\circ} \mathrm{C}$ in the dark, and the absorbance was measured at $517 \mathrm{~nm}$ against a blank. The antioxidant activity (AA) radical scavenging activity was expressed in $\mathrm{EC}_{50} \cdot{ }^{38}$

\section{Ferric ion reducing antioxidant power (FRAP) assay}

The FRAP assay was performed as described by Benzie et al. ${ }^{\mathbf{4 1}}$ with slight modifications. The FRAP reagent was prepared by mixing $38 \mathrm{mM}$ sodium acetate (anhydrous) in milli $\mathrm{Q}$ water $(\mathrm{pH}$ 3.6), $20 \mathrm{mM} \mathrm{FeCl}_{3} \cdot 6 \mathrm{H}_{2} \mathrm{O}$ in milli Q water and $10 \mathrm{mM} \mathrm{2,4,6-tri(2-}$ pyridyl)-s-triazine (TPTZ) in $40 \mathrm{mM} \mathrm{HCl}$ in proportions of $10: 1: 1$. This reagent was freshly prepared before each experiment. The FRAP reagent was added to the DHP sample $(0.1 \mu \mathrm{M}$, $1 \mu \mathrm{M}, 10 \mu \mathrm{M}$ and $100 \mu \mathrm{M})$, and the mixture was incubated at $37{ }^{\circ} \mathrm{C}$ for $40 \mathrm{~min}$ in the dark. The absorbance of the resulting solution was measured at $593 \mathrm{~nm}$ by a spectrophotometer. The FRAP values were expressed in $\mathrm{EC}_{50}{ }^{38}$

For the calculation of the $\mathrm{EC}_{50}$ values for all antioxidant assays, the absorbance values were transformed into log and then, a curve with nonlinear regression was obtained using the GraphPad Prism program. In the experiments, six replicates were used and the results were expressed as mean and confidence interval (95\%).

\section{Lipophilicity calculations}

The physicochemical parameter $\operatorname{clog} P$ (the logarithm of the $n$ octanol/water partition coefficient, $P$, based on established chemical interactions) was calculated using ACD/Chemsketch (Freeware) 2017.1.2: Advanced Chemistry Development, Inc.

\section{Cluster analysis}

The cluster analysis groups a system of variables into clusters on the basis of similarities such that each cluster represents a specific process in the system. The cluster analysis was performed to interpret the variability in the antioxidant activity of different substances. Through this analysis, it was possible to obtain the cluster in which the substances studied were grouped by similarity in antioxidant activity and the groups of molecules were organized by the quality of the results; the PAST software was used for these analyses. ${ }^{42}$

\section{Conflicts of interest}

The authors declare no conflict of interest.

\section{Acknowledgements}

The authors are thankful for the financial support from Fundação de Amparo à Pesquisa do Estado do Rio Grande do Sul (FAPERGS/PRONEM 11/2069-0), and Conselho Nacional de Desenvolvimento Científico e Tecnológico (CNPq). Fellowships from CNPq and Coordenação de Aperfeiçoamento de Pessoal de Nivel Superior (CAPES) are also acknowledged. 


\section{References}

1 A. Hantzsch, Justus Liebigs Ann. Chem., 1882, 215, 1-82.

2 H. G. O. Alvim, E. N. da Silva Junior and B. A. D. Neto, $R S C$ Adv., 2014, 4, 54282-54299.

3 R. C. Cioc, E. Ruijter and R. V. A. Orru, Green Chem., 2014, 16, 2958-2975.

4 M. G. Sharma, D. P. Rajani and H. M. Patel, R. Soc. Open Sci., 2017, 4, 170006.

5 J. P. Wan and Y. Liu, RSC Adv., 2012, 2, 9763-9777.

6 R. F. Affeldt, E. V. Benvenutti and D. Russowsky, New J. Chem., 2012, 36, 1502-1511.

7 V. K. Sharma and S. K. Singh, RSC Adv., 2017, 7, 2682-2732.

8 Z. Zarnegar, J. Safari and Z. Mansouri-Kafroudi, Catal. Commun., 2015, 59, 216-221.

9 S. Rostamnia and A. Hassankhani, Synlett, 2014, 25, 27532756.

10 D. C. Cabrera, S. B. Rosa, F. S. Oliveira, M. A. G. Marinho, C. R. M. D'Oca, D. Russowsky, A. P. Horn and M. G. M. D'Oca, Med. Chem. Commun., 2016, 7, 2167-2176.

11 G. L. Balaji, K. Rajesh, M. Venkatesh, S. Sarveswari and V. Vijayakumar, RSC Adv., 2014, 4, 39-46.

12 P. N. Kalaria, S. P. Satasia and D. K. Raval, Eur. J. Med. Chem., 2014, 78, 207-216.

13 H. Paidepala, S. Nagendra, V. Saddanappu, A. Addlagatta and B. Das, Med. Chem. Res., 2014, 23, 1031-1036.

14 J. Sherma, J. AOAC Int., 2018, 101, 1285-1294.

15 L. Ciesla, Med. Chem., 2012, 8, 102-111.

16 S. R. H. Fard, R. Miri and A. A. Nekooeian, Res. Pharm. Sci., 2016, 11, 497-504.

17 K. Varatharajan and D. S. Pushparani, Renewable Sustainable Energy Rev., 2018, 82, 2017-2028.

18 L. A. Pham-Huy, H. He and C. Pham-Huy, Int. J. Biomed. Sci., 2008, 4, 89-96.

19 S. K. Powers, J. C. Quindry and A. N. Kavazis, Free Radical Biol. Med., 2008, 44, 193-201.

20 D. Lloyd-Jones, R. J. Adams, T. M. Brown, M. Carnethon, S. Dai, G. De Simone, T. B. Ferguson, E. Ford, K. Furie, C. Gillespie, A. Go, K. Greenlund, N. Haase, S. Hailpern, P. M. Ho, V. Howard, B. Kissela, S. Kittner, D. Lackland, L. Lisabeth, A. Marielli, M. M. McDermott, J. Meigs, D. Mozaffarian, M. Mussolino, G. Nichol, V. L. Roger, W. Rosamond, R. Sacco, P. Sorlie, R. Stafford, T. Thom, S. Wasserthiel-Smoller, N. D. Wong and J. Wylie-Rosett, Circulation, 2010, 121, 46-215.

21 D. J. Hausenloy and D. M. Yellon, J. Clin. Invest., 2013, 123, 92-100.

22 E. Santa-Helena, S. Teixeira, M. R. Castro, D. C. Cabrera, C. R. M. D'Oca, M. G. M. D'Oca, A. P. Votto, L. E. M. Nery and C. A. N. Gonçalves, Biomed. Pharmacother., 2017, 92, 356-364.
23 E. Santa-Helena, D. C. Cabrera, S. Teixeira, J. Rodrigues, M. Catro, M. G. M. D'Oca, L. E. M. Nery and C. A. N. Gonçalves, Biomed. Pharmacother., 2019, 109, 1532-1540.

24 D. C. Cabrera, E. Santa-Helena, H. P. Leal, R. R. de Moura, L. E. M. Nery, C. A. N. Gonçalves, D. Russowsky and M. G. M. D'Oca, Bioorg. Chem., 2019, 84, 1-16.

25 Y. Xiao-Hui, Z. Ping-Hu, Z. Yong-Hong, L. Cheng-Guo, L. Xiao-Yu and C. Jing-Fang, ARKIVOC, 2011, 10, 327-337.

26 O. M. Nosrat, R. Sahar and G. P. Fateme, Arch. Pharm. Chem. Life Sci., 2015, 348, 1-8.

27 F. S. De Oliveira, P. M. De Oliveira, L. M. Farias, R. C. Brinkerhoff, R. C. M. A. Sobrinho, T. M. Treptow, C. R. M. D'Oca, M. A. G. Marinho, M. A. Hort, A. P. Horn, D. Russowsky and M. G. M. D'Oca, Med. Chem. Commun., 2018, 9, 1282-1288.

28 M. M. Moraes, T. G. M. Treptow, W. K. O. Teixeira, L. A. Piovesan, M. G. M. D'Oca and A. P. S. Votto, Bioorg. Chem., 2017, 72, 148-155.

29 A. C. H. Weber, T. C. Batista, B. Gonçalves, C. R. L. Hack, L. M. Porciuncula, T. G. M. Treptow, C. R. M. D'Oca, D. Russowsky and M. G. M. D'Oca, J. Am. Oil Chem. Soc., 2016, 93, 1399-1406.

30 R. C. Brinkerhoff, H. F. Tarazona, P. M. de Oliveira, D. F. Flores, C. R. M. D'Oca, D. Russowsky and M. G. M. D'Oca, RSC Adv., 2014, 4, 49556-49559.

31 A. E. Ruijter and R. V. A. Orru, Drug Discovery Today, 2013, 10, 15-20.

32 L. Jianping, Q. Jikuan, L. Huijuan and Z. Guisheng, Chin. J. Chem., 2011, 29, 511-514.

33 H. D. Fontecha-Tarazona, R. C. Brinkerhoff, P. M. de Oliveira, S. B. Rosa, D. C. Flores, C. R. D'Oca, D. Russowsky and M. G. M. D'Oca, RSC Adv., 2015, 5, 59638-59647.

34 S. Rostamnia and E. Doustkhah, J. Mol. Catal. A: Chem., 2016, 411, 317-324.

35 O. Erel, Clin. Biochem., 2004, 37, 277-285.

36 S. B. Kedare and R. P. Singh, J. Food Sci. Technol., 2011, 48, 412-422.

37 M. M. Moraes, T. G. M. Treptow, W. K. O. Teixeira, L. A. Piovesan, M. G. M. D'Oca and A. P. S. Votto, Bioorg. Chem., 2017, 72, 148-155.

38 R. Re, N. Pellegrini, A. Proteggente, A. Pannala, M. Yang and C. Rice-Evans, Free Radical Biol. Med., 1999, 26, 1231-1237.

39 Z. Chen, R. Bertin and G. Froldi, Food Chem., 2013, 138, 414420.

40 O. P. Sharma and T. K. Bhat, Food Chem., 2009, 113, 12021205.

41 I. F. F. Benzie and J. J. Strain, Anal. Biochem., 1996, 239, 7076.

42 S. M. Yidanaa, D. Ophoria and B. Banoeng-Yakubo, J. Environ. Manage., 2008, 86, 80-87. 